（34）岩盤内深部で観測された近距離地票動特性

料間組技術研究所 正会員 山口 靖紀

$\begin{array}{lllr}\text { 同上 } & \text { 过田 } & \text { 满 } \\ \text { 同 上 } & \text { 脇田 } & \text { 和試 } \\ \text { 同 上 } & \text { 新井 } & \text { 伸夫 }\end{array}$

1.まえがき

高い耐震性が要求される重要構造物の地下立地の検討に際しては、空洞の地震時挙動および岩盤内におけ る地莀動特性の把握が必要となる。そこで筆者らは、それらの問題を明らかにすることを目的として、1983 年 7月より東日本旅客鉄道株式会社および鉄道総合技術研究所と共同で J R 伊東線新宇佐美卜ンネルにおい て地票観測を行ってきている。本報告は、その地震観測で得られた記録のうち、震源距離の比較的短いもの に着目して、岩盤内深部での加速度、速度の最大振幅特性の把握を試みたものである。

\title{
2. 観測システムおよび抽出した記録の概要
}

$\mathrm{J} \mathrm{R}$ 伊東線新宇佐美トンネルでの観測は、主に山の被り厚さが約 $260 \mathrm{~m}$ の岳中央部100m区間で実施してい る。観測区間の疎密波速度およびせん断波速度はそれぞれ、2.3〜 $3.2 \mathrm{~km} / \mathrm{sec}$ よび1.1〜1.6km/secとなっている。図-1に地震観測計 器全体の配置図を示す。加速度計 $A-1 \sim A-8$ 測定成分は $X 、 Y 、$ Z の三成分で、X成分はトンネル軸方向 $\left(N 13^{\circ} 23^{\prime} 35^{\prime}\right.$ ” E)、Y方 向は軸直角方向 $\left(575^{\circ} 36^{\prime} 25^{\prime} \mathrm{E}\right) 、 \mathrm{Z}$ 方向は鉛直方向である。

1983年 7月から1987年 3月までの期間に、1984年 9月の伊豆半 島東方沖群発地震 35 個を含む60個の地震が観測されている。今回 は、そのうち震源距離が比較的短いと判断される（60 km程度以内） 44個の地震を取り上げることとする。それらの地震のマグニチュ ードは、3.0〜4.0のものがほとんどである。今回検討した記録は すべて観測システム最下点（A-6)でのものである。観測記録の例

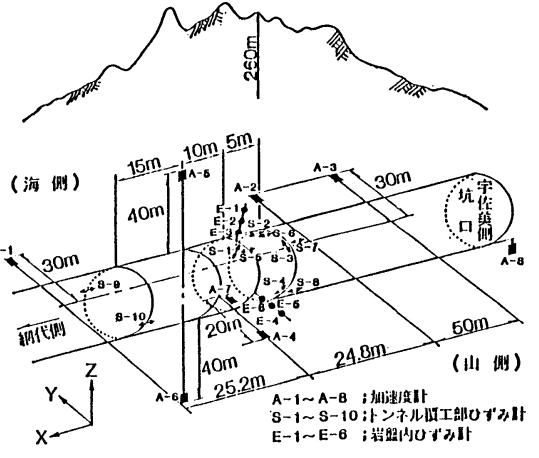

図-1 地票観測計器配置図 を図-2に示す。

1984年9月1日 $(M=4.0, \Delta 17.2 \mathrm{~km})$

\section{3. 加速度の最大振幅について}

3.1 マグニチュード、震源距離と加速度最大振幅の 関係

現在まで多数提案されてきている地表での最大加速 度を推定する式は、計算が簡単なこともあって重要構 造物の耐震設計等に頻繁に用いられてきている。よっ て、それらの式の本観測記録への適用性を検討してお くことは必要なことであると考えられる。

そこでまず、加速度水平動成分の最大振幅と震源距 離の関係を従来の提案式と比較し、代表的な提案式の 適用性の検討を行った。その結果を図-3に示す。ここ では水平動の最大值として X成分、Y成分の最大值の どちらか大きい方を採用した。図-3には、比較検討の ため Kanai et al.(1966) ${ }^{1)}$ の式、田村・他(1979) ${ }^{2}$

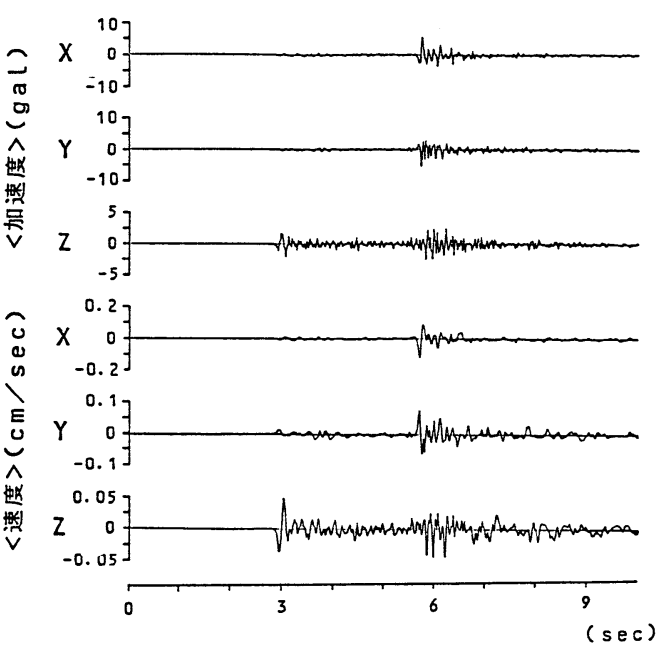

図-2 钼測記録の例 
の式、Campbell $(1981)^{3)}$ の式について、観測された地震のマ100.0 グニチュードの範囲を考虑し、マグニチュード 3.0、 それぞれに対応する曲線を併記した。ただし、Campbellの式 におけるマグニチュードには気象庁マグニチュードをそのま ま採用し、Kanai et al.の式中用いる地震動の卓越周期はつ ーリエ・スペクトルの卓越周期を参考に0.15secとした。

図-3から、以下の事項が明らかとなった。

(1) Kanai et al.の式は岩盤上での加速度最大值を予測する 式であり、震源距離が $1 \mathrm{~km}$ 程度ときわめて短くなると推定さ れる最大加速度が発散してしまうという問題を持っているが、 今回扱ったマグニチュードおよび震源距離の範囲では観測結 果の傾向を説明しうる。ただし絶対値については、観測結果 の方が小さい値を示す傾向がある。これは岩盤内深部と岩盤

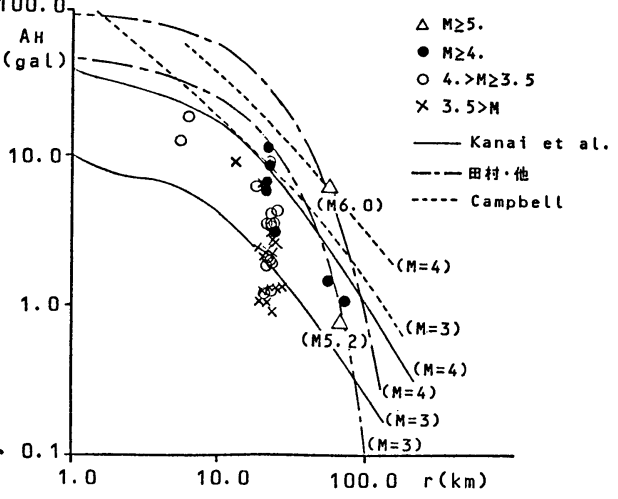

図一－３水平加速度最大值とマグニチュード、 震源距離の関係 上の差を意味しているとも考えられる。

(2)田村・他および Campbell の式は、観測結果に比べてかなり大きい值を与える式となっている。その理 由としては、対象とする值が岩盤上（提案式）と岩盤内深部（観測結果）のむのであることによる差以外に、 これらの提案式がここで扱った様な規模の小さい地震を考慮の対象としていないため、適用範囲外のものと なっている可能性が考えられる。また、Campbellにおいては岩盤上の観測結果だけでなく沖積地盤上での観 測結果も用いていることから、表層地盤の増幅の影響を取り込んだものになっているためとも考えられる。

\section{2 震源距離 $20 \mathrm{~km}$ 付近での最大振幅とマグニチュードの関係}

（1）水平動成分について

最大振幅特性については、本来ならば前述したようなマグニチュードと震源（震央）距離を取り込んだ回 㷌式上で議論を行うべきであるが、距離を変数とするほど観測データがないことから、ここでは、震源距離 が20km付近のデータ群（1984年 9月の伊豆半島東方沖群発地震）に注目し距離の項は一定とみなして、マグ ニチュードとの関係に絞って従来の式との比較を試みることと する。図-4は、加速度最大值のうち水平成分について比較した ものである。最小自乗法を適用した回帰式は、

$\log \mathrm{A}_{H}=0.588 \mathrm{M}-1.644$ （相関係数 $0.70 ）$ となる。図には先にあげた 3 つの提案式の他に、伊豆半島地域 で観测された近距離地震動を扱った澤田・他 $(1978)^{4)}$ と田中・ 他 $\left.(1980)^{5}\right)$ 2つの式むあわせて示した。

図-4から、まず、今回得られた回帰式の傾き（マグニチュー ドに関する係数）が従来の提案式と良く一致していることが分 かる。また、観测結果は、澤田・他の式を除いて、ここで取り 上げた提案式により予想される值よりも小さい値を示している。 澤田・他の式については、扱っている地震の震源距離が本観測 結果より若干長いために小さい值を取っているとも考えられる。

Kanai et al. (1966) $(r=20, T=0.15)$

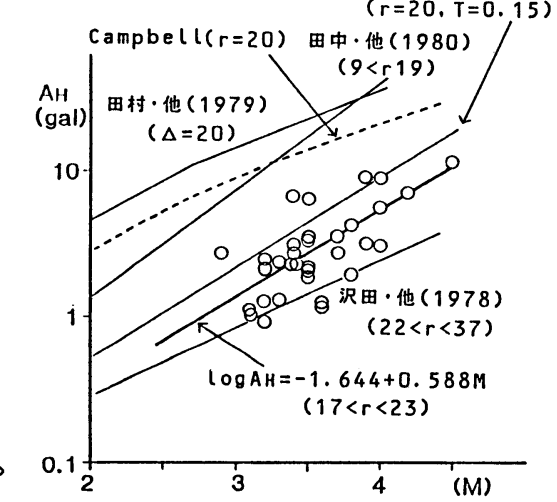

図-4 マグニチュードと水平成分の加速度最大値

一方、ここで示したようにマグニチュードと最大振幅の関係がほぼ線形な形で表現されうることは、この データ群が、震源を点と見なしても差し支えない規模と距離の関係を持ったものであったことを示唆してい ると思われる。よって、ここで示した関係は、ごく近距離で大地震が発生した場合には震源を点として評価 できなくなるため成り立たなくなる可能性があることに留意しておく必要がある。 


\section{（2）上下動成分について}

加速度上下動成分の最大值については、水平動成分に対して提案されているような推定式は見うけられな い。しかし上下動成分についてもその特性を把握しておくことは重要なこ

とであると思われる。そこで、上下動成分の加速度最大值についてマグニ チュードとの関係を検討した。検討結果を図-5に示す。得られた回帰式は、

$\log \mathrm{A}_{U}=0.549 \mathrm{M}-1.701$ （相関係数 0.65 )

である。今後は、このような推定式を発展させ、震源（颜央）距離をも取 り込んだ予測式が求められるべきであると考えられる。

（3）上下動と水平動の振幅比について

岩盤上の加速度水平動成分に関する推定式は多数提案されてきている。 また、岩盤上と岩盤内深部の最大振幅には相関があると考えられること から、岩盤内深部における水平動成分と上下動成分の振幅比の一般的傾 向が把握できれば、岩盤内深部の上下動成分の最大值をある程度推定する ことができると考えられる。ここで取り上げた観測結果の水平動成分と上 下動成分の加速度最大值の関係は、図-6に示すように、

$\log \mathrm{A}_{U}=0.878 \log \mathrm{A}_{H}-0.141$ (相関係数 0.87 ) であった。また、上下動成分の水平動成分に対する比は $0.3 \sim 1.5$ とな っており、かなり大きな值を取る可能性むあることがわかる。

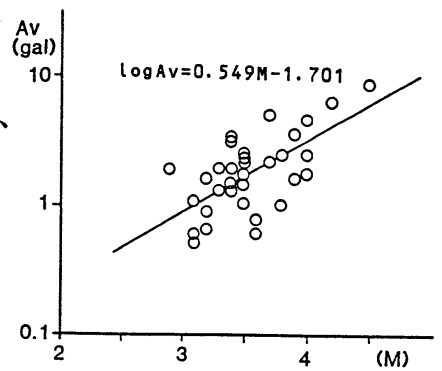

図ー5 マグニチュードと上下成分の

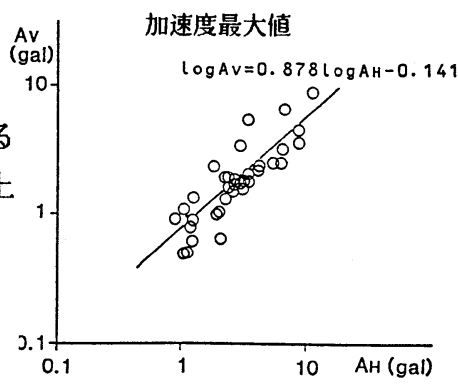

図-6 加速度の水平成分最大值と

\section{4. 速度の最大振幅について}

筆者らは、波動伝播に対する歪の理論的な検討や観測結果の 検討から、岩盤あるいは岩盤内空洞の歪の大きさはそこでの速 度振幅に比例する、という報告を行っている6)。このことから、 岩盤内での速度最大振幅と地震の規模、震源（萇央）距離の関 係を把握しておくことは重要であると考えられる。そこでまず、 加速度の場合と同様に最大振幅と震源距離の関係を図示し従来 の提案式と比較検討を行った。その結果を 図-7 に示す。図中 併記したのは、加速度と同様速度に関しても提案されている Kanai et al.1'の式のマグニチュード 3.0、3.5、4.0亿対応す る曲線である。この図から、今回の観測結果の範囲では Kanai et al.の式は全体の傾向を良く 説明していることがうかがえる。 ただし観測結果の絶対値は岩盤 内深部での値であるためか、加 速度の場合と同様に提案式より 小さい值を示している。

次に、震源距離 $20 \mathrm{~km}$ 付近の地 震群に着目して、その水平動成 分の最大值 $(X 、 Y$ のどちらか

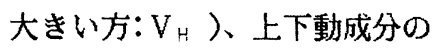
最大值 $\left(V_{U}\right)$ とマグニチュード

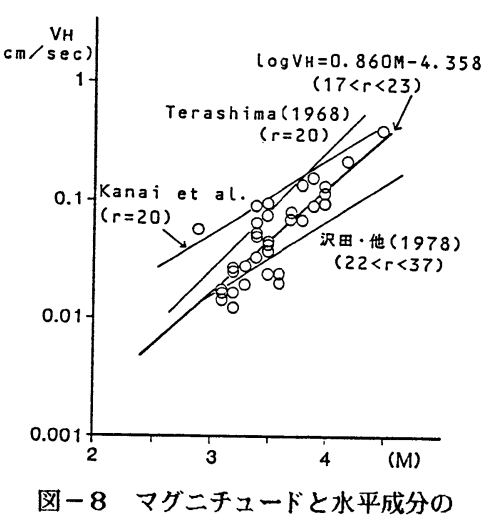

速度最大値 上下成分最大值

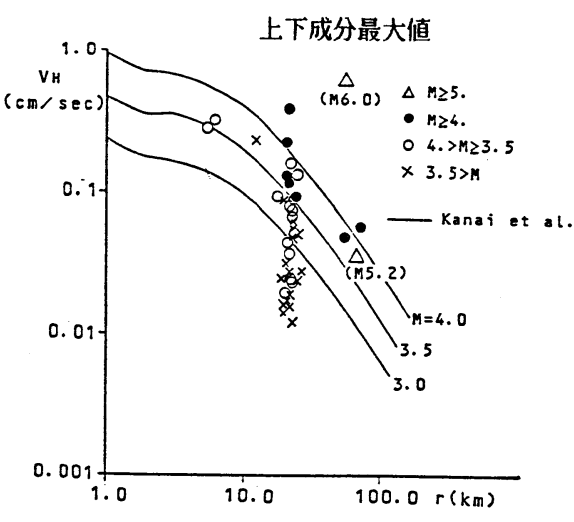

图一７水平速度最大値とマグニチュード、 震源距離の関係

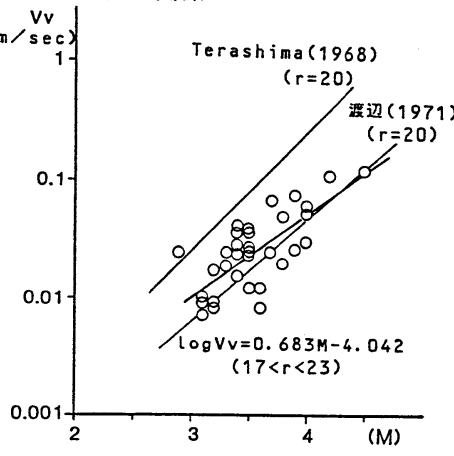

図-9 マグニチュードと上下成分の 速度最大值 
の関係を検討した。検討結果を図-8、9 に示す。回㷌式はそれぞれ以 下のようになった。

$$
\begin{array}{lll}
\log V_{H}=0.860 \mathrm{M}-4.358 & \text { (相関係数 } & 0.82 ） \\
\log V_{U}=0.683 \mathrm{M}-4.042 & \text { (相関係数 } & 0.73 ）
\end{array}
$$

それぞれの図には、前述の Kanai et al.の他に澤田・他 ${ }^{4}$ による式 を比較のため重社描きするとともに、参考のため速度最大振幅加らマ グニチュードを推定するTerashima $(1968)^{7) 、 ~}$ 渡辺 $(1971)^{81}$ の式を示 した。

水平動成分については、観測結果はKanai et al.の式により予測さ れる值より若干小さい值を示している。また、図-10に水平動成分と 上下動成分の関係を示す。回帰式は、

$$
\log \mathrm{V}_{U}=0.823 \log \mathrm{V}_{H}-0.539 \text { （相関係数 } 0.93 ）(6)
$$

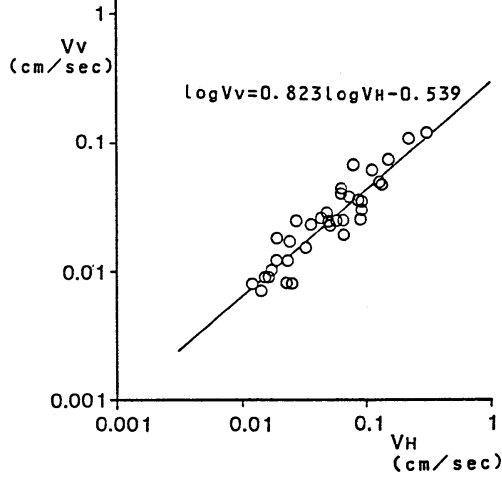

図-10 速度の水平成分最大值と 上下成分最大値

である。速度記録における上下動成分の水平動成分に対する比は0.3〜1.0となっている。

\section{5.まとめ}

J R 伊東線新宇佐美トンネルで得られた、1983年 7月から1987年 3月までの観測結果のうち震源距離が比 較的短いと判断される44個の地震に着目し、加速度と速度の最大振幅に関する考察を行い以下の結果を得た。 (1) 震源距離と最大振幅との関係において、震源距離が $20 \mathrm{~km}$ 程度以下の範囲では、観測結果とkanai et al. の式の傾向は良く一致している。ただし、その絶対値は、観測結果の方が提案式から予想される值に比べ若 干小さい。

(2) 震源距離 $20 \mathrm{~km}$ 程度の（伊豆半島東方沖群発地震の）データをもとにしたマグニチュードと最大振幅の関 係式において、回帰式の傾き（マグニチュードに関する係数）はKanai et al.や澤田・他の提案式と良い一 致を示している。

(3) 上下動成分の最大值の水平動成分の最大值に対する比率は加速度で $0.3 \sim 1.5$ 、速度で $0.3 \sim 1.0$ とな っている。

\section{6.あとがき}

ここでは、岩盤内空洞の耐震性を検討する上で重要となる近距離地震動特性のうち、主に最大振幅特性に ついて観测結果にもとづいた記述を試みた。今後はデータの蓄積を待つとともに周波数特性む含め、より詳 しく近距離地震動特性を把握できるよう検討をすすめていく必要があると考えられる。

なお、本観測は東日本旅客鉄道株式会社および鉄道総合技術研究所と共同で実施しているものであり、観 湘結果の公表を快くお許しいただいた関係各位に感謝いたします。

<参考文献>

( 1) Kanai et al.:0bservation of strong earthquake motions in Matsushiro area, Part.1 (Empirical formulae of strong earthquake motions), Bull. Earthq. Res. Inst., vol.44, pp.1269-1296, 1966.

（2）田村・他 : 岩盤地帯の地震動の最大加速度について, 第15回地震工学研究発表会講演概要集, pp.181184, 1979. (3) Campbell, K. W.: Near-source attenuation of peak horizontal acceleration, Bull. Seism. Soc. Am., vol.71, pp.2039-2070, 1981.（4）澤田 -他:伊豆大島近海地震前・余震群の近距離岩盤 上における加速度波形の特性,第5 回地震工学シンボジウム講演集, pp.233-240, 1978.( 5) 田中・他:1980 年伊豆半島東方沖地震および同群発地票の加速度強震記録と最大加速度デー夕,地震研究所集報, vol.55, pp.1043-1064，1980.（6）山口・他：山岳トンネルにおける空洞および周辺岩盤の地震時挙動 一空洞のひ ずみと周辺岩盤の挙動の関係についてー,第7回地震工学シンポジウム講演集, pp.1849-1854, 1986.（ 7) Terashima, T:Magnitude of microearthquake and the spectra of microearthquake waves, Bull. IISEE, vol.5, pp.31-108, 1968.（8）渡辺晃：近地地震のマグニチュード,地震 2, vol.24, pp.189-200, 1971. 